\title{
Is Currency Depreciation Expansionary? The Case of South Korea
}

\author{
$\mathrm{Yu} \mathrm{Hsing}{ }^{1}$ \\ ${ }^{1}$ Department of Management \& Business Administration, College of Business, Southeastern Louisiana University, \\ Hammond, Louisiana, United States \\ Email: yhsing@selu.edu
}

\begin{abstract}
Applying the aggregate demand-aggregate supply model and based on a sample during 2000.Q4-2016.Q1, this paper finds that aggregate output in South Korea is negatively affected by real depreciation of the Korean won, the real interest rate and the expected inflation rate are positively associated with government debt as a percent of GDP, lagged U.S. real GDP and growth of labor productivity. A major policy implication is that real depreciation of the Korean won would help exports but cause import costs and domestic inflation to rise and capital outflows.
\end{abstract}

Keywords: Currency depreciation, government debt, productivity growth, interest rates.

\section{Introduction}

The Korean won (KRW) had been volatile during financial crises. During the Asian financial crisis, the KRW/USD exchange rate changed from 854.0714 in 1997.M1 to 1707.3000 in 1998.M1, suggesting that the value of the won plunged $99.9 \%$ against the U.S. dollar. In the recent global financial crisis, the KRW/USD exchange rate changed from 981.7348 in 2008.M3 to 1449.6159 in 2009.M3, and the value of the won declined $47.66 \%$. In recent months in 2016, the KRW/USD exchange rate stayed in a relatively narrow range between 1145.7967 and 1216.2285. Whether changes in the KRW/USD exchange rate would help or hurt the Korean economy remains to be seen as findings of previous studies are inconclusive.

This paper attempts to focus on the relationship between the depreciation of the Korean won and aggregate output in South Korea based on aggregate demand and aggregate supply analysis. Other potential relevant variables will be considered as well. The paper differs from most other studies because a simultaneous-equation model consisting of aggregate demand and aggregate supply is applied.

\section{The Model}

We specify that aggregate demand in South Korea is determined by the inflation rate, government spending, government tax revenue, the real interest rate, foreign income, and the real exchange rate and that in the short-run aggregate supply function, real GDP supplied is affected by the inflation rate, labor productivity, and the expected inflation rate. We can express the aggregate demand and aggregate supply functions as:

$$
\begin{gathered}
Y^{d}=w\left(\pi, G, T, R, Y^{*}, \varepsilon\right) \\
Y^{s}=z\left(\pi, P, \pi^{e}\right)
\end{gathered}
$$

\footnotetext{
where

$Y^{d}=$ aggregate demand,

$\Pi=$ the inflation rate,

$G=$ government spending,

$T=$ government tax revenue,

$R=$ the real interest rate,

$Y^{*}=$ foreign income,
} 
$\varepsilon=$ the real exchange rate defined as units of the Korean won per U.S. dollar times relative prices in the U.S. and South Korea,

$Y^{s}=$ short-run aggregate supply,

$P=$ labor productivity, and

$\pi^{e}=$ the expected inflation rate.

In equilibrium, $\mathrm{Y}^{\mathrm{d}}=\mathrm{Y}^{\mathrm{s}}$. Solving for the two endogenous variables, $\mathrm{Y}$ and $\pi$, we have the equilibrium real GDP:

$$
\begin{gathered}
\bar{Y}=f\left(\varepsilon, G-T, R, Y^{*}, P, \pi^{e}\right) \\
? \quad ? \quad-+\quad+-
\end{gathered}
$$

Because government debt is an accumulation of government budget deficits, $\mathrm{G}-\mathrm{T}$, we use government debt as a percent of GDP (D) as a proxy for fiscal policy $\pi^{e}$

$$
\begin{gathered}
\bar{Y}=h\left(\varepsilon, D, R, Y^{*}, P, \pi^{e}\right) \\
? ?-+\quad+-
\end{gathered}
$$

We expect that equilibrium real GDP has a positive relationship with foreign income and labor productivity and a negative relationship with the real interest rate and the expected inflation rate.

Whether real depreciation would increase or reduce real GDP has been examined extensively. Real depreciation makes Korean goods and services cheaper and more competitive, increases Korea's exports, and shifts aggregate demand to the right. On the other hand, real depreciation makes imported goods and services more expensive, raises domestic inflation, and shifts the short-run aggregate supply curve to the left. The net effect on real GDP is unclear.

Based on the AD/AS model and a sample of 15 countries, Gylfason and Risager [18] examine the impact of devaluation on aggregate output and the current account for eight developing countries and seven industrialized countries. For South Korea, a $10 \%$ currency devaluation would increase gross national product by $0.4 \%$ and the current account by $2.5 \%$.

Morley [25] analyzes the effect of devaluation during stabilization programs for twenty-eight LDCs including South Korea. He specifies that capacity utilization is a function of monetary policy, fiscal policy, the terms of trade, export growth, import growth and a dummy variable. He finds that a 10 percentage point real devaluation would lead to a $1 \%$ decrease in capacity utilization. It would take at least 2 years for the full impact to realize. After devaluations, external factors were beyond the control of LDC policymakers. If there is an increase in foreign lending, the probability of a recession would decrease as most LDCs are constrained by foreign reserves.

Based on a sample of twenty-three LDCs including South Korea during 1973.Q1-1988.Q4, BahmaniOskooee [1] specifies that real output is a function of the real effective exchange rate, government spending, the money supply, and the terms of trade. He finds that except for Barbados, there is no evidence that currency devaluation would be contractionary due to lack of support for cointegration. Using a sample of five Asian countries including South Korea during 1976.Q1-1999.Q4, BahmaniOskooee, Chomsisengphet, and Kandil [2] postulate that real output is determined by the real effective exchange rate, government spending, the money supply, foreign income and the energy cost. They show that real depreciation is neutral for South Korea, contractionary for Indonesia and Malaysia, and expansionary for the Philippines and Thailand. Bahmani-Oskooee and Miteza [3] review previous studies. They indicate that early studies based on the aggregate demand model overlook the aggregate supply side and that applying the aggregate demand-aggregate supply model is the right approach. They conclude that real currency depreciation may be expansionary or contractionary depending upon countries under study, model specifications, methodologies employed in empirical work, sample periods, and other factors.

Kalyoncu, Artan, Tezekici and Ozturk [21] study the effect of currency devaluation on aggregate output for twenty-three OECD countries. Real output is specified as a function of the real exchange rate. In the short run, currency devaluation is expansionary in Hungary and Switzerland, contractionary in Finland, Germany and Turkey, and neutral in other remaining countries including South Korea. In the long run, currency devaluation has a positive impact in Finland, Germany and Sweden and a negative effect on aggregate output in Austria, Hungary, Poland, Portugal, Switzerland and Turkey.

According to Woodford [27], monetary policy is not expected to have an effect on the real exchange rate in the long run, and the impact of nominal devaluation on the real exchange rate would not last 
long. He argues that the evidence that real devaluation promotes growth is less convincing and that growth is caused by many other factors as well.

Kim, An and Kim [22] investigate the relationship between the exchange rate and output and capital flows for six developed countries and seven developing countries including South Korea. They specify a VAR model including real output, the nominal effective exchange rate, the current account, the capital account, the relative price level, real money supply. Foreign income and the foreign interest rate are two exogenous variables. Currency devaluation is likely to be expansionary in developed nations but contractionary in developing economies. The current account tends to improve in countries with depreciating currency. Capital inflows would increase output in developing nations but would not affect output in developed countries.

The effect of the government debt/deficit as a percent of GDP is unclear. Barro [4,5] argues that the impact of debt- or deficit-financed government spending on real output is neutral because its effect is cancelled out by more saving made by households who anticipate more future taxes to pay off the debt. Feldstein [15], Hoelscher [20], Cebula [7], Cebula and Cuellar [10], Cebula [8,9], Cebula, Angjellari-Dajci, and Foley [11] and others indicate that more government deficit/debt raises real interest rates and is likely to crowd out spending by households and businesses. On the other hand, McMillin [24], Gupta [17], Darrat [12,13], Findlay [16], Ostrosky [26] and others maintain that more government deficit/debt would not raise the interest rate.

\section{$3 \quad$ Empirical Results}

Data sources came from the International Financial Statistics published by the International Monetary Fund, the Bank of Korea and the St. Louis Federal Reserve Bank. Real GDP in South Korea is measured in billion won. The nominal exchange rate is measured as units of the won per U.S. dollar. The real exchange rate is calculated as the nominal exchange rate times the relative consumer price indexes in the U.S. and South Korea, respectively. Government debt is measured as a percent of GDP. The real interest rate is equal to the corporate bond yield minus the expected inflation rate. Productivity is defined as real output in million won per worker. U.S. real GDP measured in billion is selected to represent foreign income. The expected inflation rate is estimated as the average inflation rate of the past four quarters. To reduce potential multicollinearity problems, lagged U.S. real GDP and percent change in labor productivity are used in empirical work. An analysis of the data shows that the impact of the real exchange rate on real GDP has shifted upward since 2008.Q4. Hence, a binary variable with a value of one during 2008.Q4 - 2016.Q1 is included. Real GDP in South Korea, the real exchange rate and lagged U.S. real GDP are on a log scale. The sample ranges from 2000.Q4 to 2016.Q1. The data for government debt before 2000.Q4 is not available.

Figures 1 and 2 show time trends of two major variables, namely, the real exchange rate and government debt as a percent of GDP. The real exchange rate rose significantly during 2007.Q4 2009.Q1, declined substantially during 2009.Q2 - 2014.Q3, and then rose again since 2014.Q4. Government debt as a percent of GDP seems to continue to rise over time. Tables 1 and 2 report the basic statistical analysis and the simple correlation between real GDP and the right-hand side variables. Table 3 presents the unit root test. As shown, except for the real interest rate, other time series variables have unit roots in level at the $5 \%$ level. All the time series variables do not have unit roots in first difference at the $1 \%$ level.

Table 4 presents the estimated regression and related statistics. The variance equation based on EGARCH is presented in the notes in Table 1. EGARCH is selected because the non-negative constraints are not required, there are less restrictions on the parameters, and bad news yields more volatility than good news in financial analysis. The seven right hand side variables can explain approximately $98.62 \%$ of the variation in real GDP. All the explanatory variables are significant at the $1 \%$ or $2.5 \%$ level. Real GDP is positively affected by government debt as a percent of GDP, lagged U.S. real GDP and productivity growth and negatively influenced by the real exchange rate or real depreciation of the won, the real interest rate and the expected inflation rate. A $1 \%$ real depreciation of the won versus the U.S. dollar would reduce real GDP by $0.0457 \%$ whereas a 1 percentage-point increase in government debt as a percent of GDP would increase the log of real GDP by 0.0019. These results suggest that the negative impacts of real depreciation of the won such as higher import costs, 
higher domestic inflation and capital outflows outweigh the positive impacts such as more exports and that more government debt as a percent of GDP would not hurt real GDP.

Several other variables are considered. An increase in the real crude oil price is expected to shift the short-run aggregate supply curve to the left, causing the inflation rate to rise and the equilibrium real GDP to decline. When the real crude oil price is included in the regression, its coefficient is positive and significant at the $1 \%$ level. However, the coefficient of the real exchange rate becomes positive and significant at the $10 \%$ level mainly due to a high degree of multicollinearity. An increase in the real equity price tends to increase household wealth and improve business financial standing, which would cause consumption and investment expenditures to rise, shift aggregate demand to the right, and raise the equilibrium real GDP. When the real equity price index is included in the regression, its coefficient is positive and significant at the $1 \%$ level, suggesting that a higher real equity price would result in a higher equilibrium real GDP. Nevertheless, the inclusion of the real equity price index causes the coefficient of the real exchange rate to become positive and significant whereas the correlation coefficient between real GDP and the real exchange rate is -0.4975. Due to a high degree of multicollinearity among some of the variables, we may need to reduce one or more right-hand side variables in the regression in order to include the real equity price and/or the real oil price. Another way to mitigate the problem is to change the sample size to find if the results may change. Because this paper's focus is on whether real depreciation would be expansionary, we may need to specify a different model in another paper to examine the impact of the real equity price on aggregate output.

\section{$4 \quad$ Summary and Conclusions}

This paper has examined whether real depreciation of the Korean won would help or hurt aggregate output in South Korea. Based on aggregate demand and aggregate supply analysis, the equilibrium real GDP is a function of the real exchange rate, government debt as a percent of GDP, the real interest rate, foreign income, labor productivity, the expected inflation rate, and a binary variable representing an upward shift of the impact of the real exchange rate on real GDP. According to empirical results, real appreciation of the Korean won versus the U.S. dollar, a higher government debt as a percent of GDP, a lower real interest rate, a higher lagged U.S. real GDP, growth of labor productivity, and a lower expected inflation rate would raise real GDP. The impact of real depreciation of the won on real GDP has shifted upward since 2008.Q4. This paper makes contributions to the literature because of the application of a simultaneous-equation model, proper measurement of fiscal policy, consideration of labor productivity in short-run aggregate supply, and the use of EGARCH in empirical work.

There are several policy implications. Recent appreciation of the Korean won versus the U.S. dollar seems to affect real GDP in South Korea positively. The trend of declining long-term interest rates since 2009 is conducive to business investment spending, aggregate demand, and aggregate output. Although rising government debt as a percent of GDP has a positive impact of real GDP, the authorities may need to pursue a prudent fiscal policy so that government debt would be sustainable in the long run.

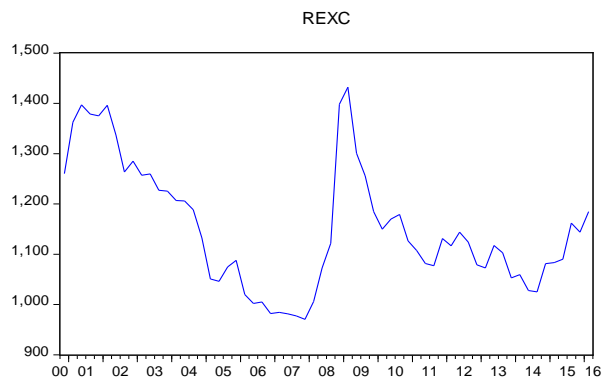

Figure 1. Time trend of the real exchange rate (REXC) 


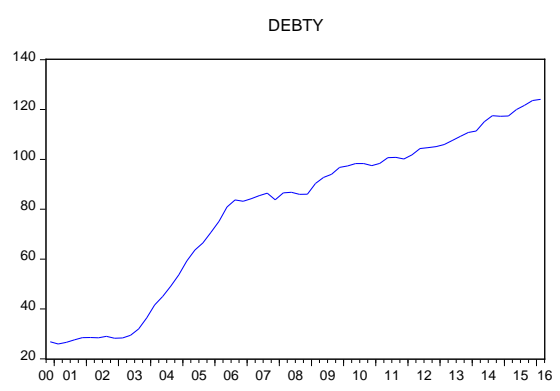

Figure 2. Time trend of government debt as a percent of GDP (DEBTY)

Table 1. Basic statistical analysis

\begin{tabular}{lcccccccl}
\hline & $\log (\mathbf{Y})$ & $\log (\boldsymbol{\varepsilon})$ & $\mathbf{D}$ & $\mathbf{R}$ & $\mathbf{L o g}\left(\mathbf{Y}^{*}\right)$ & $\mathbf{P}$ & $\pi^{e}$. & \multicolumn{1}{l}{ Binary } \\
\hline Mean & 12.57203 & 7.043473 & 19.82294 & 6.746200 & 9.580136 & 7.355126 & 2.779994 & 0.483871 \\
Median & 12.59011 & 7.025772 & 21.62086 & 6.820543 & 9.592929 & 7.275532 & 2.787284 & 0.000000 \\
Maximum & 12.82765 & 7.267019 & 31.01694 & 9.887752 & 9.709332 & 26.44339 & 4.680430 & 1.000000 \\
Minimum & 12.24380 & 6.877780 & 6.490998 & 4.613160 & 9.442063 & -9.664731 & 0.687987 & 0.000000 \\
Std. Dev. & 0.170468 & 0.104477 & 7.994693 & 1.099481 & 0.075747 & 8.381611 & 1.001156 & 0.503819 \\
Skewness & -0.256382 & 0.434608 & -0.519126 & 0.587908 & -0.363063 & 0.240384 & -0.316725 & 0.064550 \\
Kurtosis & 1.886775 & 2.322733 & 1.891205 & 3.528544 & 2.206534 & 2.424927 & 2.361306 & 1.004167 \\
Jarque-Bera & 3.880676 & 3.136759 & 5.960763 & 4.293245 & 2.988520 & 1.451441 & 2.090402 & 10.33338 \\
Probability & 0.143655 & 0.208383 & 0.050773 & 0.116878 & 0.224415 & 0.483976 & 0.351621 & 0.005703 \\
Sum & 779.4659 & 436.6953 & 1229.022 & 418.2644 & 593.9684 & 456.0178 & 172.3596 & 30.00000 \\
Sum Sq. Dev. & 1.772616 & 0.665845 & 3898.822 & 73.74043 & 0.349990 & 4285.335 & 61.14117 & 15.48387 \\
Observations & 62 & 62 & 62 & 62 & 62 & 62 & 62 & 62 \\
\hline
\end{tabular}

Table 2. Simple correlation analysis

\begin{tabular}{cc}
\hline Variable & $\mathrm{Y}$ \\
\hline $\mathrm{Y}$ & 1 \\
$\varepsilon$ & -0.4975 \\
$\mathrm{D}$ & 0.9680 \\
$\mathrm{R}$ & 0.0908 \\
$\mathrm{Y}^{*}$ & 0.9660 \\
$\mathrm{P}$ & 0.9839 \\
$\pi^{e}$ & 0.5234 \\
Binary & 0.8471 \\
\hline
\end{tabular}

Table 3. The ADF unit root test

\begin{tabular}{lcc}
\hline Variable & Test Statistic in Level & Test Statistic in First Difference \\
\hline $\mathrm{Y}$ & -0.2498 & -6.7861 \\
$\varepsilon$ & -2.4084 & -5.8523 \\
$\mathrm{D}$ & -1.3276 & -4.2649 \\
$\mathrm{R}$ & -3.5324 & -5.9444 \\
$\mathrm{Y}^{*}$ & -0.4425 & -4.9762 \\
$\mathrm{P}$ & -2.7100 & -7.2936 \\
$\pi^{e}$ & -0.8797 & -5.0622 \\
Binary & -0.9365 & -7.8740 \\
\hline
\end{tabular}


Table 4. Estimated regression of $\log ($ real GDP) for South Korea

\begin{tabular}{lcc}
\hline Variable & Coefficient & z-Statistic \\
\hline Log(real exchange rate) & -0.0457 & -2.3667 \\
Government debt/GDP ratio & 0.0019 & 6.0251 \\
Real interest rate & -0.0069 & -4.1070 \\
Log(lagged U.S. real GDP) & 1.2847 & 41519.50 \\
Growth of labor productivity & 0.0013 & 8.8273 \\
Expected inflation rate & -0.0059 & -4.8837 \\
Binary variable & 0.1314 & 23.8566 \\
Intercept & 0.5404 & 4.0964 \\
R-squared & 0.9862 & \\
Adjusted R-squared & 0.9844 & \\
Akaike info criterion & -5.4653 & \\
Schwarz criterion & -5.1222 & \\
Mean absolute percent error & $1.4171 \%$ & \\
Estimation methodology & EGARCH & \\
Sample period & 2000.Q4 - 2016.Q1 & \\
Sample size & 62 & \\
\hline
\end{tabular}

Notes: The binary variable has a value of one since 2008.Q4 and zero otherwise. All the coefficients are significant at the $1 \%$ or $2.5 \%$ level. EGARCH stands for the exponential GARCH method. The estimated variance equation and the z-statistic in the parenthesis are as follows:

$\mathrm{LOG}(\mathrm{GARCH})=-10.2171+2.3207 * \operatorname{ABS}(\operatorname{RESID}(-1) / @ \operatorname{SQRT}(\operatorname{GARCH}(-1))) *(-26.3759) *(6.2069)$

Acknowledgements. I am very thankful to three anonymous referees for insight comments.

\section{References}

1. Bahmani-Oskooee, M., "Are devaluations contractionary in LDCs?" Journal of Economic Development, vol. 23, no. 1, pp. 131-144, 1998.

2. Bahmani-Oskooee, M., Chomsisengphet, S., \& Kandil, M., "Are devaluations contractionary in Asia?" Journal of Post Keynesian Economics, vol. 25, no. 1, pp. 69-82, 2002.

3. Bahmani-Oskooee, M. and Miteza, I., "Are devaluations expansionary or contractionary? A survey article," Economic Issues, vol. 8, no. 2, pp. 1-28, 2003.

4. Barro, R. J., "Are government bonds net wealth?” Journal of Political Economy, vol. 82, pp. 1095-1117, 1974.

5. Barro, R. J., "The Ricardian approach to budget deficits," Journal of Economic Perspectives, vol. 3, pp. 37-54, 1989.

6. Buchanan, James M., "Perceived wealth in bonds and social security: A comment," Journal of Political Economy, vol. 84, pp. 337-342, 1976.

7. Cebula, R. J., "An empirical note on the impact of the federal budget deficit on ex ante real long term interest rates, 1973-1995," Southern Economic Journal, vol. 63, pp. 1094-1099, 1997.

8. Cebula, R. J., "Impact of federal government budget deficits on the longer-term real interest rate in the US: Evidence using annual and quarterly data, 1960-2013," Applied Economics Quarterly, vol. 60, no. 1, pp. 23-40, 2014a.

9. Cebula, R. J., "An empirical investigation into the impact of US federal government budget deficits on the real interest rate yield on intermediate-term treasury issues. 1972-2012," Applied Economics, vol. 46, pp. 3483-3493, 2014b.

10.Cebula, R. J. and P. Cuellar, "Recent evidence on the impact of government budget deficits on the ex-ante real interest rate yield on Moody's Baa-rated corporate bonds," Journal of Economics and Finance, vol. 34, pp. 301$307,2010$. 
11.Cebula, R. J., F. Angjellari-Dajci and M. Foley, "An exploratory empirical inquiry into the impact of federal budget deficits on the ex post real interest rate yield on ten year treasury notes over the last half century," Journal of Economics and Finance, vol. 38, pp. 712-720, 2014.

12.Darrat, A. F., "Fiscal deficits and long-term interest rates: Further evidence from annual data," Southern Economic Journal, vol. 56, pp. 363-373, 1989.

13.Darrat, A. F., "Structural federal deficits and interest rates: Some causality and cointegration tests," Southern Economic Journal, vol. 56, pp. 752-759, 1990.

14.Feldstein, M., "Perceived wealth in bonds and social security: A comment," Journal of Political Economy, vol. 84, pp. 331-336, 1976

15.Feldstein, M., "Government deficits and aggregate demand," Journal of Monetary Economics, vol. 9, pp. 1-20, 1982.

16.Findlay, D. W., "Budget deficits, expected inflation and short-term real interest rates: Evidence for the US," International Economic Journal, vol. 4, pp. 41-53, 1990.

17.Gupta, K. L., "Budget deficits and interest rates in the US," Public Choice, vol. 60, pp. 87-92, 1989.

18.Gylfason, T. and M. Schmid, "Does devaluation cause stagflation?" Canadian Journal of Economics, pp. 641-654, 1983.

19. Gylfason, T. and O. Risager, "Does devaluation improve the current account?" European Economic Review, vol. 25, pp. 37-64, 1984

20.Hoelscher, G., "New evidence on deficits and interest rates," Journal of Money, Credit, and Banking, vol. 18, pp. $1-17,1986$.

21.Kalyoncu, H., S. Artan, S. Tezekici and I. Ozturk, "Currency devaluation and output growth: An empirical evidence from OECD Countries," International Research Journal of Finance and Economics, vol. 14, pp. 232-238, 2008.

22.Kim, G., L. An, and Y. Kim, "Exchange rate, capital flow and output: Developed versus developing economies," Atlantic Economic Journal, 43, pp. 195-207, 2015.

23.Lane, P. R. and J. C. Shambaugh, "Financial exchange rates and international currency exposures," American Economic Review, vol. 100, no. 1, pp. 518-540, 2010.

24.McMillin, W. D., "Federal deficits and short-term interest rates," Journal of Macroeconomics, vol. 8, pp. 403-422, 1986.

25.Morley, S. A., "On the effect of devaluation during stabilization programs in LDCs," Review of Economics and Statistics, vol. 74, pp. 21-27, 1992.

26. Ostrosky, A. L., "Federal government budget deficits and interest rates: Comment," Southern Economic Journal, vol. 56, pp. 802-803, 1990 .

27.Woodford, M., "Is an undervalued currency the key to economic growth?" Columbia Working Paper Series, No. 0809-13, 2009. 